\title{
Correction to: Mating and aggressive behaviour of Brachyrhaphis olomina (Cyprinodontiformes: Poeciliidae)
}

\author{
Carlos A. Garita-Alvarado ${ }^{1,2,4} \cdot$ Beatriz Naranjo-Elizondo ${ }^{2,3} \cdot$ Gilbert Barrantes $^{2}$
}

Published online: 31 December 2018

(c) The Author(s) 2018

\section{Correction to: J Ethol (2018) 36:1-13 https://doi.org/10.1007/s10164-017-0523-y}

The article Mating and aggressive behaviour of Brachyrhaphis olomina (Cyprinodontiformes: Poeciliidae), written by Carlos A. Garita-Alvarado, Beatriz Naranjo-Elizondo and Gilbert Barrantes was originally published electronically on the publisher's internet portal (currently SpringerLink) on 21 August, 2017 without open access. With the author(s)' decision to opt for Open Choice the copyright of the article changed on 18 December, 2018 to (C) The Author(s) 2018 and the article is forthwith distributed under the terms of the Creative Commons Attribution 4.0 International License (http://creativecommons.org/licenses/by/4.0/), which permits use, duplication, adaptation, distribution and reproduction in any medium or format, as long as you give appropriate credit to the original author(s) and the source, provide a link to the Creative Commons license and indicate if changes were made.

The original article has been corrected.

Open Access This article is distributed under the terms of the Creative Commons Attribution 4.0 International License (http://creativecommons.org/licenses/by/4.0/), which permits unrestricted use, distribution, and reproduction in any medium, provided you give appropriate credit to the original author(s) and the source, provide a link to the Creative Commons license, and indicate if changes were made.

The original article can be found online at https://doi.org/10.1007/ s10164-017-0523-y.

Carlos A. Garita-Alvarado

cagaritab@gmail.com

1 Sistema de Estudios de Posgrado en Biología, Universidad de Costa Rica, San José 11501-2060, Costa Rica

2 Escuela de Biología, Universidad de Costa Rica, San José 11501-2060, Costa Rica

3 Centro de Investigación en Ciencias del Mar y Limnología, Universidad de Costa Rica, San José 11501-2060, Costa Rica

4 Instituto de Biología, Universidad Nacional Autónoma de México, Tercer Circuito Exterior S/N., C.P. 04510 CDMX, México 